\title{
FOGAZOTT FELÜLETPÁROK KAPCSOLÓDÁSGEOMETRIAI ÉS GYÁRTÁSGEOMETRIAI FELADATAINAK MEGOLDÁSA A SURFACE CONSTRUCTOR PROGRAMMAL
}

\author{
Dudás László
}

\section{KIVONAT}

Kapcsolódó felületpárok ismeretlen tagjának burkoló eljárással való meghatározására, valamint diszkrét élekkel rendelkezō szerszámokkal való elóállításának modellezésére alkalmas szoftver, a Surface Constructor kerül bemutatásra a cikkben. A szoftver által alkalmazott matematikai modell a szerzõ kutatásának eredménye, eltér a szokásos, pl. Litvin-féle modelltől. Alkalmas az érintkezési vonal, a burkolt felület és a fellépõ alámetszések meghatározására, szabadon választható származatató felület és relatív mozgás esetén. A program további újdonsága a szimbolikus számítás alkalmazása, melynek révén magát a kinematikai modellalkotási folyamatot modellezi, és konkrét felülettől és mozgásviszonytól független tervezői keretrendszerként mũkődik. Az emlitett geometriai objektumok meghatározásán és megjelenitésén túl mozgásszimulációra is alkalmas. A lehetōségek egy részét a kð̋vetkező eredményeken keresztül mutatjuk be: ellipszis tengelymetszeti profilú csigával kapcsolódó csigakerékfog-felület meghatározása , spiroid tányérkerék lefejtőmarása és globoid csiga kőszorülésének modellezése.

\section{BEVEZETÉS}

Kapcsolódó konjugált felületpárok ismeretlen tagjának meghatározására tőbb etjárás ismeretes:

- a Gohman-féle differenciálgeometriai módszer, valamint

- a kinematikai módszer, mely az $n \cdot v^{l, 2}=0$ feltételt alkalmazza a kapcsolódás szükséges feltételeként, ahol $\boldsymbol{n}$ a felületi normálvektor, $\boldsymbol{v}^{12}$ pedig a vizsgált pontbeli relatív sebesség vektora.

A Surface Constructor (továbbiakban: SC) programban alkalmazott elérés modellröl a terjedelmi korlátok miatt csak a következöket mondhatjuk: az Fl származtató felület adott a Kl Descartes koordinátarendszerben (továbbiakban: KR), valamint a $\kappa$ görbevonalú $K R$-ben. Mindkét KR és Fl is rögzített. $A$ $\kappa \mathrm{KR}$ speciálisan van megalkotva: koordinátairányai közül az $R$ és a $T$ a feladathoz igazodóan, a $\Phi$ pedig olymódon van felvéve, hogy a $\Phi=0$ koordinátafelületbe eső pontokból kiinduló $\Phi$ koordinátavonalak ugyanezen pontoknak az F2 keresett felületet tartalmazó tér mozgatásakor leirt mozgáspályáit adják. 
Ennek, és az alkalmazott elérés-folyamatnak köszönhetöen egy F2 felületi pont megtalálása egy egyváltozós függvény lokális minimumának megtalálására vezet. A minimumfeladat diszkussziója megadja a lokális alámetszések ósszes formajját, a minimumfeladat megoldásának kiterjesztése egy adott mozgás-, ill. idötartományra pedig elvezet a globális elmetszés jelenségéhez, amely lehetővé teszi az interferencia nagyságának számszerüsitését is. Mindez részletesen megtalálható az [1] irodalomban. A továbbiakban az Elérés-modellre épülö SC program kerül bemutatásra. Az SC az F2 keresett felület meghatározására az $\mathrm{R}=\mathrm{R}(\Phi)$ függvény diszkrét kinematikai szimulációval elöállitott pontjait használja.

Az SC program fontos tulajdonsága, hogy az F1 származtató felület és az F1 és F2 közötti kinematikai viszony megadására szimbolikus algebrai eszközrendszert használ. Képes az F1 felület létrehozására egy szimbolikus formában megadott térgörbe és a térgörbe mozgásának ismeretében, elvégezve egy szimbolikus mátrix-vektor szorzást. Az összes összetett kinematikai láncot elemi KR-viszonyok, mint homogén koordinátás szimbolikus mátrixok szorzásával, ill. invertálással származtatja. Ilymódon az SC egy kinematikai modellek megalkotására alkalmas keretrendszer, mely magát a modellalkotási folyamatot modellezi, és "paramétereinek", a szimbolikus geometriai és kinematikai összefüggéseknek a megadásával egy adott feladat kinematikai modelljének alakját ölti, mely a numerikus változóinak, paramétereinek történö értékadás után képes egy valóságos folyamat geometriai leirására, szimulálására. Az elmélet és a program használhatóságát a következökben példákon keresztül mutatjuk be.

\section{ELLIPSZIS SZÁRMAZTATÓGÖRBÉJÜ CSIGAHAJTÁS VIZSGÁLATA}

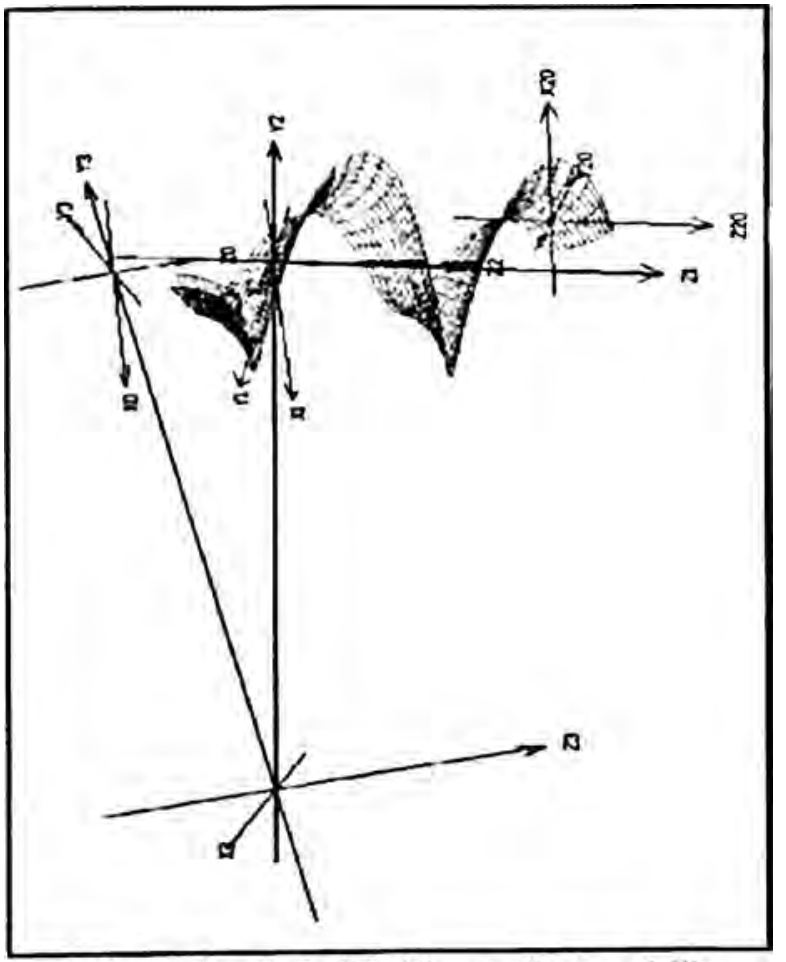

I.ábra A csigahajtás kinematikai modellje
A csigahajtások kapcsolódási tulajdonságainak javitása folyamatos igény. A csiga tengelymetszetében körív generálógörbével rendelkezö csigahajtás jó kapcsolódási jellemzöiröl több publikációban számoltak be. Az SC programmal megvizsgálhatjuk egy tengelymetszetben ellipszis generálógörbével rendelkezö hajtás geometriai tulajdonságait. Az alkalmazott kinematikai modell az 1. ábrán látható. Az ellipszis generáló görbe a K20 KR-ben adott. Az F1 származtató csavarfelület a K1, a számított F2 csigakerékfog-felület a K3 KRben rögzitett. Az alkalmazott globális számitási mód a valós kerékfog-felületet adja az esetleges elmetszésekkel együtt. A program bármely állónak választott KR-ben képes szimulálni a felületek és a KR-ek mozgását, megjeleniteni a vándorló érintkezési görbét. 


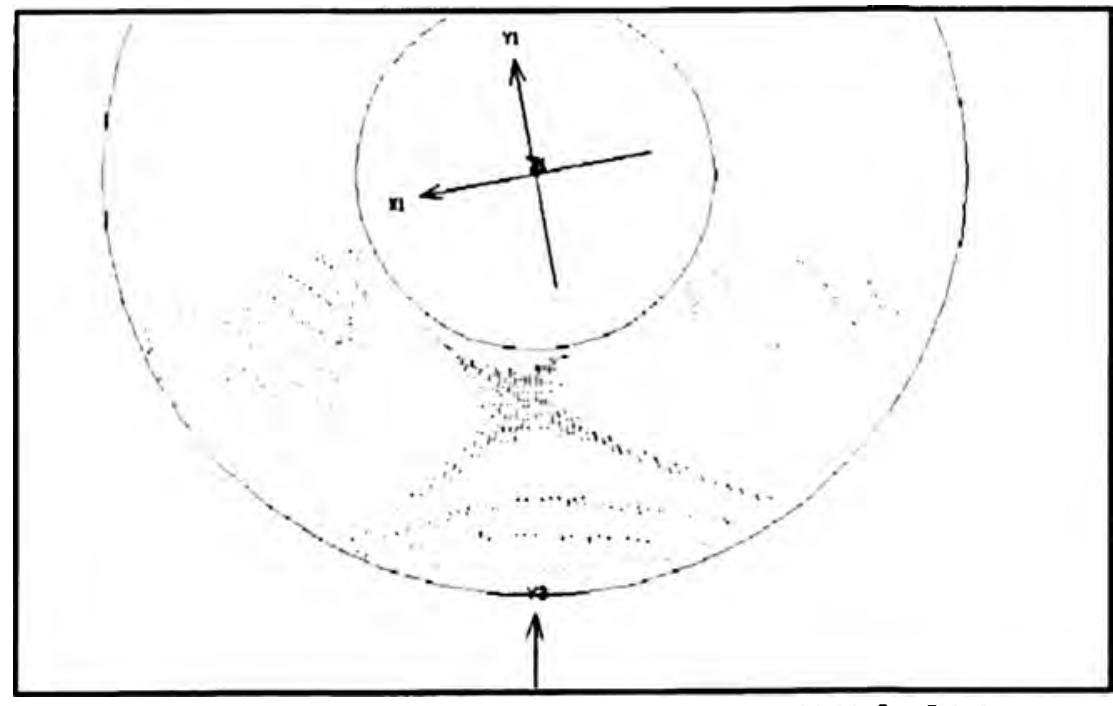

2. ábra Az érintkezési vonalak seregeként adódó fogfelület
Szemléltethetjük a származtatott F2 fogfelületet érintkezési vonalak adott sürüségü seregeként is, amint a 2. ábra mutatja. Az éppen érintkezésben lévő két görbeiv a képernyön villog. Amikor a két görbeív a fog közepén összeér, egy $\mathrm{X}$ alakú érintkezési mintázat jelenik meg egy pillanatra. A fog bal szélén elmetszés nyomai láthatók.

\section{A LEFEJTŐMARÓ FOGSZÁMÁNAK HATÁSA A FOGAZOTT FELÜLET HIBẢJÁRA}

A vizsgálatot spiroid hajtópár kerekének lefejtése esetére végeztük el. A spiroid tányérkerék egy hipoid

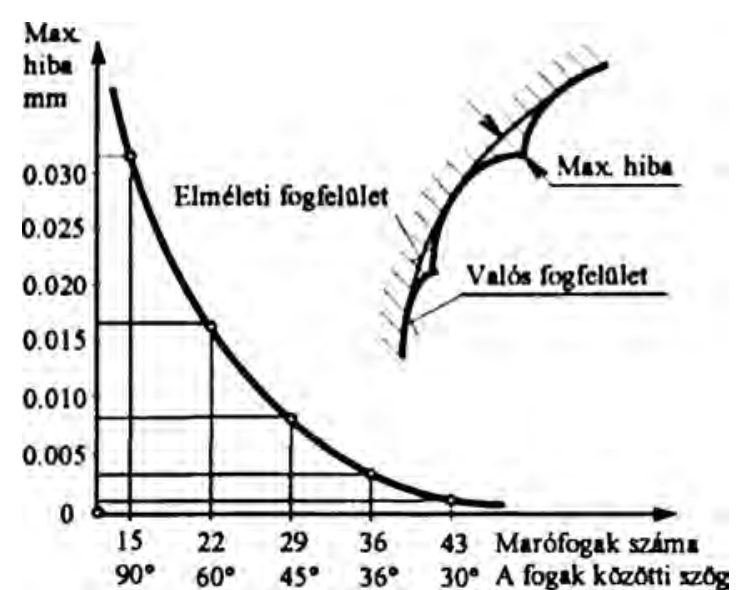

3. ábra A hiba függése a marófogszámtól fogaskerékre emlékeztet, de a vele kapcsolódó elem egy kúpos csiga. A kerék fogazásánál használt lefejtömaró is kúpos, emlékeztet egy Klingelnberg lefejtỏmaróra. A spiroid kerék lefejtett felülete a maró egyes élei által súrolt felületdarabok láncolataként adódik, és eltér az elméleti fogfelülettől, amint a 3. ábra is mutatja. A lefejtés maximális hibảja a maró fogszámának függvénye. Az alkalmazott kinematikai modell a 4. ábrán látható. A K2(x2,y2,z2) KR-ben adott kerék áll és a maró saját tengelye körül is forogva körbejárja. A kerék

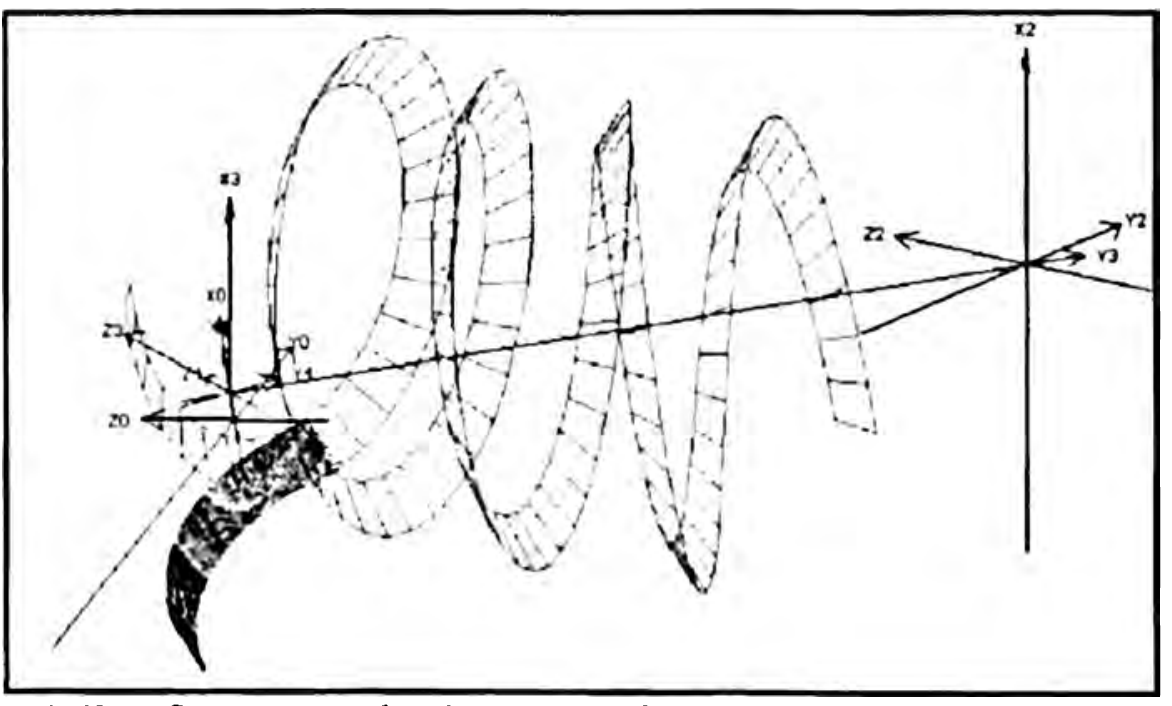

4. ábra Spiroid tányérkerék fogazásának modellje egy kész fogfelülettel tengelye a függöleges $\mathrm{x} 2 . \mathrm{Az}$ ábra a maró egyik éle által súrolt térbeli felületet is mutatja. Minden egyes marófog által forgácsolt fogfelületrész más színnel jelenik meg a képernyön. A vizsgálat eredményeként kapott hibafüggvény a 3. ábra alján látható. 


\section{KÖSZÖRÜKORONG FELÜLETÉNEK SZÁMÍTÁSA}

A globoid és a spiroid csigák elméleti pontosságú megköszörülésének egyik új lehetőségét jelenti a szerző találmánya. Ezen csigatípusok köszörülésénél nem alkalmazhatók a forgásfelület alakú korongok, mivel a csigák görbületi jellemzöi menetröl menetre változnak. Az 5. ábrán bemutatott köszörügép olyan korongot alkalmaz, melynek ugyanannyi menete van, mint a köszörülendő csigának. Egyforma szögsebességgel forognak, de az eltérő átmérő miatt az érintkezési pontokban csúszás van, amely szükséges az anyagleválasztáshoz. A 6. ábra mutatja az adott globoid csiga felületet és a korong számitott müködöfelületét. Az SC programmal meghatározható a korongfelület spiroid csigák köszörüléséhez is.

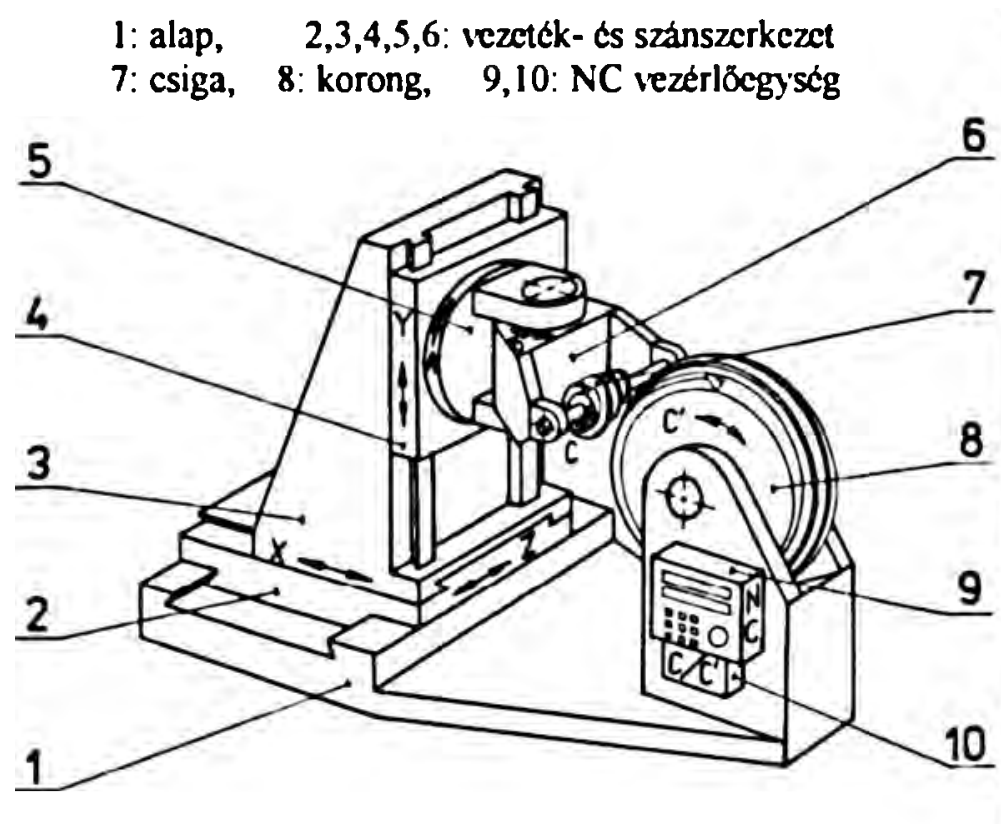

5. ábra Az új típusú köszörügép felépítése

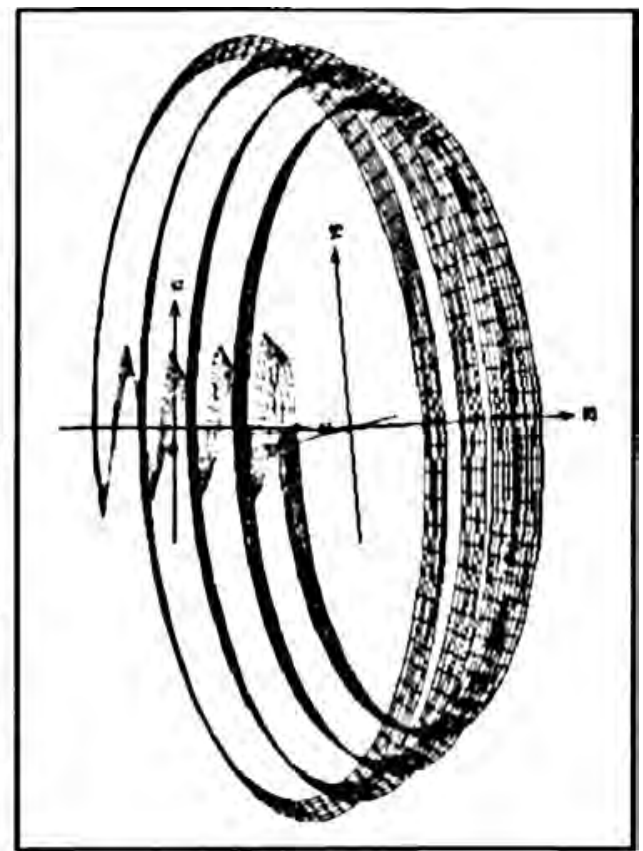

6. ábra A köszörülés modellje

\section{IRODALOMJEGYZÉK}

1. Dudás László: Kapcsolódó felületpárok gyártásgeometriai feladatainak megoldása az elérés modell alapján Kandidátusi értekezés, MTA-TMB, Budapest, 1991.

Dr.Dudás László egyetemi adjunktus, a müszaki tudomány kandidátusa

Miskolci Egyetem Alkalmazott Informatikai Tanszék, Miskolc-Egyetemváros, Magyarország, H-3515

Tel.: (36) (46) 365-111/21-12 Fax:(36) (46) 369-554

E-mail: dudaas@iit.uni-miskolc.hu 